\title{
Alkaline Anion Exchange Membranes based on KOH-treated Multilayer Graphene Oxide
}

\author{
Thomas Bayer ${ }^{\mathrm{a}, \mathrm{b}}$, Benjamin V. Cunning ${ }^{\mathrm{a}}$, Roman Selyanchyn ${ }^{\mathrm{a}}$, Takeshi Daio ${ }^{\mathrm{d}}$, Masamichi Nishihara ${ }^{\mathrm{a}}$, \\ Shigenori Fujikawa ${ }^{a}$, Kazunari Sasaki ${ }^{\text {a-d }}$, Stephen M. Lyth ${ }^{\text {a,e,f* }}$ \\ ${ }^{a}$ International Institute for Carbon-Neutral Energy Research (WPI-I2CNER); \\ ${ }^{b}$ Department of Mechanical Engineering, Faculty of Engineering; ${ }^{c}$ Next-Generation Fuel \\ Cell Research Center (NEXT-FC); \\ ${ }^{\mathrm{d}}$ International Research Center for Hydrogen Energy; \\ Kyushu University, Nishi-ku, Fukuoka, 819-0395, Japan \\ ${ }^{\mathrm{e}}$ School of Chemical and Process Engineering, University of Leeds, LS2 9JT, UK \\ ${ }^{\mathrm{f}}$ Department of Mechanical Engineering, University of Sheffield, S10 2TN, UK
}

\begin{abstract}
A novel class of alkaline anion exchange membrane (AAEM) is presented, in the form of $\mathrm{KOH}-$ modified multilayer graphene oxide paper $\left(\mathrm{GO}_{\mathrm{KOH}}\right)$. Such membranes can be easily fabricated at large scale with varying thickness using conventional filtration techniques, and have high tensile strength (24.5 MPa). However, a large degree of swelling is observed. SEM investigations show that the morphology of GO changes after $\mathrm{KOH}$-treatment, whilst XPS measurements and XRD analysis confirm successful chemical modification. The hydrogen gas permeability is several orders of magnitude lower than conventional polymer-based ionomer membranes. The maximum anion conductivity is $6.1 \mathrm{mS} / \mathrm{cm}$ at $70^{\circ} \mathrm{C}$, and the dominant charge carrier is confirmed to be $\mathrm{OH}^{-}$by utilization of anion and proton-conducting blocking layers. The ion exchange capacity is $6.1 \mathrm{mmol} / \mathrm{g}$, measured by titration. A water-mediated reverse Grotthuss-like mechanism is proposed as the main diffusion mode of $\mathrm{OH}^{-}$ions. Finally, a prototype AAEM fuel cell is fabricated using a $\mathrm{GO}_{\mathrm{KOH}}$ membrane, confirming the applicability to real systems.
\end{abstract}

\section{Keywords}

Alkaline fuel cell, anion exchange membrane, fuel cells, graphene oxide, ionic conductivity

\section{Introduction}

Ion exchange membranes are selectively permeable to specific ions whilst generally being insulating to electrons. The charge carriers can be cations (e.g. $\mathrm{H}^{+}$, or $\mathrm{Li}^{+}$), or anions (such as $\mathrm{OH}^{-}$). Ion exchange membranes have important industrial applications in electrodialysis (e.g. seawater desalination, demineralization, food processing, and glycerin purification), and electrolysis (e.g. water splitting, and the chloralkali process for $\mathrm{Cl}_{2}$ and $\mathrm{NaOH}$ production) [1,2]. In particular, they are a fundamental component in polymer electrolyte membrane fuel cells (PEFCs), providing mechanical support, an electron barrier, and high through-plane ionic conductivity [1,3]. The most commonly utilized ion exchange membranes are proton exchange membranes (PEMs) such as $\mathrm{Nafion}^{\circledR}$ (E.I. DuPont de Nemours \& Co., Inc.), Flemion ${ }^{\mathrm{TM}}$ (Asahi Glass, Japan), Neosepta-F ${ }^{\mathrm{TM}}$ (Tokuyama, Japan), and Aciplex $^{\mathrm{TM}}$ (Asahi Kasei Chemicals Corporation, Japan) [4,5]. Nafion ${ }^{\mathbb{B}}$ is by far the most-used membrane in PEFCs [3] due to high proton conductivity $(>0.1 \mathrm{~S} / \mathrm{cm}$ ), good mechanical properties (e.g. 29.4 MPa tensile strength) and excellent chemical stability [6]. Automobile manufacturers focus on Nafion-based PEFCs for fuel cell vehicles (e.g. Toyota MIRAI, Japan), and stationary combined heat 
and power fuel cell systems (e.g. Enefarm, Japan) also mainly utilize Nafion. However, the proton conductivity of Nafion depends strongly on hydration, and at $>100^{\circ} \mathrm{C}$ the mechanical stability decreases significantly. Another disadvantage is fuel crossover, which increases with operation temperature and has a big influence on performance and efficiency in both direct methanol fuel cells (DMFCs) [7], and hydrogen fuelled PEFCs [8]. Finally, the cost of Nafion is still far higher than U.S. Department of Energy targets $\left(\sim 40 \$ / \mathrm{m}^{2}\right)$ [3]. For PEFCs in general, the high cost, poor stability, and the susceptibility of platinum to $\mathrm{CO}$ poisoning are major barriers to wide-spread commercialization $[5,9-11]$.

In alkali anion exchange membranes (AAEMs), the charge carrier is a negatively charged ion, such as $\mathrm{OH}^{-}[1,2,12,13]$. The first practical alkaline fuel cells (AFCs) utilized aqueous alkali electrolytes, which presented various challenges in terms of sealing and separation. Later, solid polymer AAEMs were developed. Alkaline anion exchange membrane fuel cells (AAEMFCs) have several advantages over PEFCs [12,14-18]; non-noble metal catalysts can be used due to faster cathode reaction kinetics [19]; the alkaline environment is less corrosive than acid allowing the use of cheaper materials; and fuel crossover is reduced because electroosmotic drag is in the opposite direction compared with PEFCs. Additionally CO poisoning is diminished due to faster oxidation of $\mathrm{CO}$ in AAEMFCs. These factors can drastically reduce the cost compared with PEFC systems. There are currently several commercially available AAEMs in production: Tokuyama A 201 (Tokuyama Co. Ltd.); Aciplex (Asahi Chemical Industry Co.); Selemion (Asahi Glass Co. Ltd.); and FuMA-Tech FAD (FuMA-Tech $\mathrm{GmbH}$ ) [12]. However, none of these dominate in the same way that Nafion does in PEFCs, since no membrane satisfies all the necessary conductivity, durability, gas-permeability and cost requirements.

AAEMs can be distinguished into different classes, namely: homogenous membranes; heterogeneous membranes; hybrid membranes; and interpenetrating polymer network membranes [12,20]. Most commercially available AAEMs are fabricated from a single polymer phase, and are therefore homogeneous membranes. They are generally composed of a fluorocarbon (or hydrocarbon) polymer backbone with cationic functional side groups, which act as anion transport sites. These can be quaternary ammonium $\left(-\mathrm{NR}_{3}^{+}\right)$, phosphonium, sulfonium, or metal-based functional groups $[1,2,12,13,20]$. In heterogeneous AAEMs a polymer without intrinsic anion conduction, such as polyvinyl alcohol (PVA) or polybenzimidazole (PBI), is doped with $\mathrm{KOH}$ to induce anionic conductivity. Conductivities range from e.g. $1 \mathrm{mS} / \mathrm{cm}$ at RT [12] to e.g. $100 \mathrm{mS} / \mathrm{cm}$ at $90^{\circ} \mathrm{C}$ for high $\mathrm{KOH}$ concentrations. However, a lack of mechanical stability and leaching of $\mathrm{KOH}$ are problems that need to be solved in such membranes $[12,20]$. Hybrid membranes consist of an anion-conducting polymer combined with an inorganic component to provide mechanical strength. The conductivity is generally lower than in heterogeneous AAEMs. One example is polyethylene oxide (PEO) hybridized with siloxane $\left(\left[\mathrm{Si}\left(\mathrm{OCH}_{3}\right)_{3}\right]_{2}\right)$, with a conductivity of $3 \mathrm{mS} / \mathrm{cm}$ at RT [12]. Another is PVA-KOH hybridized with zirconia $\left(\mathrm{ZrO}_{2}\right)$, with a particularly high conductivity of $267 \mathrm{mS} / \mathrm{cm}$ at $20^{\circ} \mathrm{C}[12,21]$. In interpenetrating-polymer-network (IPN) AAEMs, two different polymers are at least partially interlaced at a molecular scale but are not covalent bonded to each other. For example, PVA can be interlaced with cationic polyelectrolytes such as polyethyleneimine (PEI), poly(diallyldimethylammonium chloride), or polyarcyamide. IPN-AAEMs usually have high chemical and mechanical stability, however conductivity is low (e. g. $3.5 \mathrm{mS} / \mathrm{cm}$ ), and decreases significantly during aging $[12,20]$.The preparation of anion exchange membranes is generally quite complicated and expensive, and the carcinogen chloromethyl methyl ether is often used [12]. Therefore the field is wide open for new mechanically strong membranes with high gas barrier properties, and good ionic conductivity.

Graphene oxide (GO) is formed by chemical oxidization and exfoliation of graphite into individual two-dimensional sheets, using e.g. Hummer's or Brodie's methods [22,23]. It is readily dispersible in water, and forms strong free-standing membranes when dried. Large, thin GO membranes can be fabricated by e.g. filtration [24], bar-coating, or printing [25,26]. GO is essentially a graphene sheet, but with hydroxyl, epoxy and carboxyl functional groups attached to the edges and basal planes. These 
oxygen-containing groups promote water uptake and can also be used as starting points for further chemical modification. GO has already been found to be beneficial in PEFC or DMFC membranes as a composite material. Blending with Nafion or sulfonated polyimides (SPI) enhances proton conductivity while decreasing methanol cross-over by an order of magnitude [27]. Nafion incorporating GO functionalized with sulfonic acid displayed high proton conductivity and fuel cell performance at $120^{\circ} \mathrm{C}$ and low relative humidity (RH), compared to recast Nafion [28]. In DMFCs, Nafion laminated with GO showed improved performance at high methanol concentration, due to suppressed cross-over [29]. Pure GO also has proton conductivity [30]. Tateishi et al. fabricated a fuel cell utilizing a $20 \mu \mathrm{m}$ multilayer GO membrane. The conductivity was $0.1 \mathrm{mS} / \mathrm{cm}$ at room temperature and $20 \% \mathrm{RH}$, and the fuel cell power density was $13 \mathrm{~mW} / \mathrm{cm}^{2}$ [31]. We have reported the proton conductivity of GO membranes $(0.6 \mathrm{mS} / \mathrm{cm})$, and achieved power densities of $34 \mathrm{~mW} / \mathrm{cm}^{2}$ in GO membrane fuel cells (GOMFCs) with $16 \mu \mathrm{m}$ thick membranes [32]. We have also explored the impedance and permittivity of such membranes in detail [33]. Functionalization of GO with sulfonated acid groups leads to even higher conductivity $(12 \mathrm{mS} / \mathrm{cm})$ and higher power densities $\left(113 \mathrm{~mW} / \mathrm{cm}^{2}\right)$ [34]. Karim et al. reported the through-plane conductivity of GO pellets with $10 \mathrm{mS} / \mathrm{cm} \mathrm{[35].} \mathrm{Recently}$ Hatakeyama et al. investigated proton conductivity in single layer and multilayer GO and reported increasing proton conductivity with increasing film thickness (from $0.04 \mathrm{mS} / \mathrm{cm}$ for a monolayer, to $0.4 \mathrm{mS} / \mathrm{cm}$ for a $200 \mathrm{~nm}$ thick membrane [36].

GO has been investigated in AAEMFC membranes, but to a much lesser extent. For example, Yang and Wang recently incorporated graphene and sulfonated graphene (obtained by thermal reduction of GO) into a PVA/chitosan composite, obtaining a conductivity of $93 \mathrm{mS} / \mathrm{cm}$ at $80{ }^{\circ} \mathrm{C}$ and doubling the tensile strength of pure PVA [37]. They did not incorporate their membrane into an AAEMFC. Movil et al. incorporated PDDA-functionalized GO into PVA-based composite membranes and observed conductivity of $21 \mathrm{mS} / \mathrm{cm}$ at $80{ }^{\circ} \mathrm{C}$, improved thermo-mechanical stability, and AAEMFC power density of $17 \mathrm{~mW} / \mathrm{cm}^{2}$ [38]. Liu et al prepared composite membranes by incorporating quaternized graphene into aryl polymers, resulting in high Young's modulus (5240 MPa) and tensile strength (205 $\mathrm{MPa}$ ), and bicarbonate conductivity of $18.7 \mathrm{mS} / \mathrm{cm}$ at $80^{\circ} \mathrm{C}$ [39]. Zarrin et al. prepared functionalized GO with quaternary ammonium groups and made a composite with PBI. The conductivity was 85 $\mathrm{mS} / \mathrm{cm}$ at $65^{\circ} \mathrm{C}$, and an AAEMFC incorporating this membrane achieved a power density of 86.7 $\mathrm{mW} / \mathrm{cm}^{2}$ at $50^{\circ} \mathrm{C}$ and $100 \% \mathrm{RH}[40]$. Finally, Chen et al. functionalized GO with imidazolium, and composited this with chitosan. The conductivity was $10 \mathrm{mS} / \mathrm{cm}$ at $90{ }^{\circ} \mathrm{C}$ and $100 \% \mathrm{RH}$, whilst the open circuit voltage (OCV) was $0.71 \mathrm{~V}$ and the maximum AAEMFC power density was $75.8 \mathrm{~mW}$ $\mathrm{cm}^{-2}$ [41]. All of the above work has been on GO composited with well-known anion conducting materials. To date, the conductivity and fuel cell performance of pure-GO-based AAEMs has not been reported.

Here we report the preparation and characterization of a novel heterogeneous anion exchange membrane based on multilayer graphene oxide paper. Reacting carboxyl or hydroxyl groups with $\mathrm{KOH}$ results in the following neutralization reaction, forming a carboxylate salt, or an alkoxide:

$$
\begin{aligned}
& \mathrm{RCOOH}_{(\mathrm{aq})}+\mathrm{KOH}_{(\mathrm{aq})} \leftrightarrow \mathrm{RCOO}^{-} \mathrm{K}_{(\mathrm{aq})}+\mathrm{H}_{2} \mathrm{O}_{(\mathrm{l})} \\
& \mathrm{ROH}_{(\mathrm{aq})}+\mathrm{KOH}_{(\mathrm{aq})} \leftrightarrow \mathrm{RO}^{-} \mathrm{K}_{(\mathrm{aq})}^{+}+\mathrm{H}_{2} \mathrm{O}_{(\mathrm{l})}
\end{aligned}
$$

In the case of $\mathrm{GO}$, the $\mathrm{OH}$ and $\mathrm{COOH}$ functional groups are attached to the surface of the graphene sheet. Similar surface neutralization reactions have been performed on acid-oxidized multiwall carbon nanotubes [42]. Following this neutralization with excess $\mathrm{KOH}$, the $\mathrm{GO}$ dispersion is filtered and dried to form membranes. The conductivity of these is investigated and the performance in GO-based AAEM fuel cells is presented. 


\section{2.\# Experimental}

\subsection{Preparation of multilayer graphene oxide alkali anion exchange membranes}

To make an alkaline GO dispersion, $210.8 \mathrm{mg}$ of potassium hydroxide (Wako Pure Chemical Industry, assay value $\geq 85.0 \%$ ) was dissolved in $43.01 \mathrm{ml}$ graphene oxide dispersion (Graphene Supermarket, flake size 0.5 . to $5 \mu \mathrm{m}, 5 \mathrm{mg} / \mathrm{ml}$ ) and stirred at room temperature for 24 hours. The amount of $\mathrm{KOH}$ added to the GO dispersion was calculated to be approximately stoichiometric with the oxygen functional groups on the $\mathrm{GO}$, as calculated from elemental analysis. The $\mathrm{pH}$ of the as-purchased $\mathrm{GO}$ dispersion was 2.3 before addition of $\mathrm{KOH}$, changing to 12.5 after the cation exchange reaction. Herein, $\mathrm{KOH}$-treated graphene oxide is labelled $\mathrm{GO}_{\mathrm{Kон}}$. Membranes were prepared by vacuumfiltration from dispersion onto Millipore filters (pore size $0.025 \mu \mathrm{m}, 35 \mathrm{~mm}$ diameter). These were then dried at room temperature for 48 hours and peeled off the filter, yielding freestanding and flexible $\mathrm{GO}_{\mathrm{KOH}}$ membranes.

\subsection{Morphological and Chemical Analysis}

The morphologies of the membrane surface and cross-section were investigated by scanning electron microscopy (SEM, Hitachi S-5200, $15 \mathrm{kV}$ ). Transmission electron microscopy (TEM) was performed on a JEOL ARM 200CF, with an acceleration voltage of $120 \mathrm{kV}$. Chemical composition of the membrane sample was determined using X-ray photoelectron spectroscopy (XPS, KRATOS Analytical ESCA-3400 with $\mathrm{Mg} \mathrm{K} \alpha$ radiation, $12 \mathrm{kV}, 10 \mathrm{~mA}$ ). X-ray diffraction (XRD) was measured using a Smartlab X-ray Diffractometer with $\mathrm{Cu} \mathrm{K} \alpha$ radiation $\left(\gamma=1.5418 \AA, 0.01^{\circ}\right.$ /step).

\subsection{Tensile Strength Testing}

The tensile strength of $\mathrm{GO}$ and $\mathrm{GO}_{\mathrm{KOH}}$ membranes was measured at room temperature and around $63 \%$ relative humidity (ambient lab conditions). The samples were cut into strips $10 \mathrm{~mm}$ in length and $2 \mathrm{~mm}$ wide. Tensile load was applied using a hydraulic testing machine force gauge (SHIMPO FGO$\mathrm{C}-\mathrm{TV}$ ), until rupture. Applied force and elongation were recorded. The tensile stress (S) was calculated using $\mathrm{S}=\mathrm{F} / \mathrm{A}$, where $\mathrm{F}$ is the applied force and $\mathrm{A}$ is the initial cross-sectional area of the sample. Strain $(\varepsilon)$ was calculated using $\varepsilon=\mathrm{L} / \mathrm{L}_{0} \times 100 \%$, where $\mathrm{L}$ is the length of the sample during elongation and $\mathrm{L}_{0}$ is the initial sample length. Elastic modulus $\mathrm{E}$ is defined as the slope of the stressstrain curve in the elastic region, and was calculated using $\mathrm{E}=\mathrm{S} / \varepsilon$.

\subsection{Ion Exchange Capacity (IEC)}

The $\mathrm{H}^{+}$IEC of GO membranes was immersing and sonicating the dry $\mathrm{GO}$ membrane in $1 \mathrm{M} \mathrm{NaCl}$ solution to exchange the acidic protons of $\mathrm{GO}$ with $\mathrm{Na}^{+}$. The released protons were titrated to neutral $\mathrm{pH}$ with $0.01 \mathrm{M} \mathrm{NaOH}$ solution. The $\mathrm{OH}^{-} \mathrm{IEC}$ was obtained by redispersing a dry $\mathrm{GO}_{\mathrm{KOH}}$ membrane in $15 \mathrm{~mL}$ of milli-Q $\mathrm{H}_{2} \mathrm{O}$ with the assistance of sonication. The dispersion was titrated back to the original $\mathrm{pH}$ of GO solution ( $\approx 3.5$ ) using $0.01 \mathrm{M} \mathrm{HCl}$ solution. The IECs (in $\mathrm{mmol} / \mathrm{g}$ ) were determined from the following equation, where $\mathrm{V}_{\mathrm{x}}$ and $\mathrm{C}_{\mathrm{x}}$ are the volume and concentration, respectively, of $\mathrm{NaOH}$ or $\mathrm{HCl}$ :

$$
E=\frac{V_{x} \times C_{x}}{\text { Membrane Weight }}
$$

\subsection{Water Uptake}


Water uptake and swelling were measured on $\mathrm{GO}_{\mathrm{KOH}}$ and GO samples with a size of $5 \times 5 \mathrm{~mm}^{2}$, and thicknesses of 21 and $19 \mu \mathrm{m}$, respectively. Five different samples were measured for reproducibility. The dry mass was determined using an analytical balance (Mettler Toledo XP2UV, $\pm 0.1 \mu \mathrm{g}$ ). The alkaline membranes displayed strong swelling in water, affecting the mechanical properties to the extent that handling freestanding samples was impossible. Therefore the membranes were supported on silicon wafers and a water droplet was placed over the membrane covering it completely. After saturation, excess water was carefully removed using an absobant wipe and the mass was measured. Water uptake (WU) was calculated using Equation (2), where $\mathrm{m}_{\text {wet }}$ and $\mathrm{m}_{\mathrm{dry}}$ are the wet and dry masses, respectively;

$$
W U(w t \%)=\frac{m_{w e t}-m_{d r y}}{m_{d r y}} \cdot 100 \%
$$

\subsection{Thermogravimetric Analysis}

Thermogravimetric analysis (TGA) of $\mathrm{GO}_{\mathrm{KOH}}$ and $\mathrm{GO}$ was performed under air flow $(50 \mathrm{ml} / \mathrm{min})$ using a Rigaku Thermo plus EVO2 TG8121. The samples were heated from room temperature to $1400^{\circ} \mathrm{C}$ at a rate of $5 \mathrm{~K} / \mathrm{min}$, and the change in mass was recorded as a function of temperature. The initial masses of $\mathrm{GO}$ and $\mathrm{GO}_{\mathrm{KOH}}$ were 9.72 and $10.77 \mathrm{mg}$ respectively.

\subsection{Hydrogen Permeation Rate}

For gas permeance measurements the membrane area was masked with kapton and alumina tapes to form a circle of desired diameter and area $\left(\mathrm{d}=1 \mathrm{~cm}, \mathrm{~S}=0.785 \mathrm{~cm}^{2}\right)$. Additionally, to prevent bending under vacuum the membrane is placed on a porous polycarbonate support filter $(1.2 \mu \mathrm{m}$ pore size $)$. Dry hydrogen permeation through the $\mathrm{GO}$ and $\mathrm{GO}_{\mathrm{KOH}}$ membranes was measured at $30{ }^{\circ} \mathrm{C}$ using a GTR-11A/31A gas barrier testing system with a GTR-31AKU attachment (GTR Tec Corp., Japan). A differential-pressure method is used in which gas permeation is induced by a vacuum on the permeate side and extra pressure at the feed side, as shown in the supplementary information (Figure 1a). The total pressure difference was $200 \mathrm{kPa}$, and the sample collection time at the sweep side of the membrane was 30 minutes. The collected gas was transferred to a gas chromatograph (GC) with a thermal conductivity detector (TCD) (Yanaco G3700T, Japan) and the volume measured, as shown in the supplementary information (Supplementary Figure $1 \mathrm{~b}$ ). The operation parameters of the GC are listed in the Supplementary Table 1 of supplementary information. The permeance in gas permeation units (GPU) and permeability in barrers were estimated for membranes of different thickness [43] and compared to the reference Nafion membrane.

\subsection{Ionic Conductivity}

Ionic conductivity was investigated at different temperatures and humidity using a membrane testing device (MTS-740, Scribner) coupled with an impedance analyzer (Solatron SI1260) [44]. A membrane with $37 \mu \mathrm{m}$ thickness was measured with an $\mathrm{AC}$ amplitude of $10 \mathrm{mV}$ in the frequency of $30 \mathrm{MHz}$ to $10 \mathrm{~Hz}$. The impedance was measured with increasing temperature from 30 to $70^{\circ} \mathrm{C}$, with isothermal changes in relative humidity (RH) from 100 to $0 \% \mathrm{RH}$. Before measurements, the sample was pretreated at $100 \% \mathrm{RH}$ for 4 hours, followed by 1 hour pretreatment at each humidity step. Impedance plots are fitted to an equivalent circuit using ZPlot (Scribner), from which the membrane resistance, $\mathrm{R}$ $(\Omega)$, was determined from the membrane thickness, L $(\mathrm{cm})$, and cross-sectional area, A $\left(\mathrm{cm}^{2}\right),(0.5$ $\left.\mathrm{cm}^{2}\right)$. Conductivity, $\sigma(\mathrm{S} / \mathrm{cm})$, was calculated using $\sigma=L /(R \cdot A)$.

In order to separate the anionic and protonic contributions from the total conductivity of the membranes, i.e. to confirm the anion conducting nature of the membranes, blocking layer measurements were performed. Commercially available anion conducting membranes were used as proton blocking layers (Tokuyama A201, $28 \mu \mathrm{m}$ ), and commercially available proton conducting 
membranes (Nafion ${ }^{\circledR} 212,50 \mu \mathrm{m}$ ) was used as anion blocking layers. The $\mathrm{GO}_{\mathrm{KOH}}$ membranes $(27$ and $28 \mu \mathrm{m}$, respectively) were sandwiched between the respective blocking layers, as shown in Error! Reference source not found.e. The impedance was measured as described above. The resistance of the blocking layers was determined in previous measurements, and was subtracted from the total resistance of the multilayer system. The protonic and anionic conductivity of $\mathrm{GO}_{\mathrm{KOH}}$ was finally calculated using the same equation mentioned above. 


\subsection{Fuel cell performance test}

A membrane electrode assembly (MEA) was prepared using a $\mathrm{GO}_{\mathrm{KOH}}$ membrane with a thickness of $16 \mu \mathrm{m}$. Catalyst ink was prepared by mixing Pt/C electrocatalyst (Tanaka Kikinzoku Kogyo K.K., 46.2 wt \% Pt) with $5 \mathrm{wt} \%$ anion conducting polymer solution (Tokuyama, Japan), ethanol (Chameleon, Japan), and deionized water. The catalyst ink was stirred overnight, then sonicated before use for 30 min (SMT Ultra Sonic Homogenizer UH-600). The catalyst ink was sprayed onto the $\mathrm{GO}_{\mathrm{KOH}}$ membrane (Nordson K.K. Spraying Device, C-3J) using a mask to create an electrode size of $0.5 \mathrm{~cm}^{2}$ with a catalyst loading of $0.3 \mathrm{mgPt} / \mathrm{cm}^{2}$ for both electrodes. Hydrophobic carbon paper (EC-TP1060T) gas diffusion layers (GDLs), were precisely positioned over the electrocatalyst layers. The prepared MEA was placed into a single cell test holder $\left(1 \mathrm{~cm}^{2}\right)$ and installed in a home-made fuel cell testing system. The cell was preconditioned for 30 minutes at $30^{\circ} \mathrm{C}$ and a nitrogen gas flux of 100 $\mathrm{ml} / \mathrm{min}(95 \% \mathrm{RH})$. The gas flux was changed to hydrogen and air $(100 \mathrm{ml} / \mathrm{min}, 95 \% \mathrm{RH})$ and after ten minutes a performance test was conducted. Polarization curves and power density were investigated using a VersaSTAT-4 (Amtek).

\section{3.\# Results and Discussion}

\subsection{Microscopy}

Error! Reference source not found. (a-d) shows surface and cross-sectional SEM images of GO and $\mathrm{GO}_{\mathrm{KOH}}$ membranes. Both $\mathrm{GO}$ and $\mathrm{GO}_{\mathrm{KOH}}$ membranes have a layered structure, characteristic of multilayer GO paper. However, the $\mathrm{GO}_{\mathrm{KOH}}$ membrane surface is more strongly corrugated, with more prominent surface features than the GO membrane. Such corrugation has been observed in, for example, reduced GO [45]. Alternatively, the change in morphology may be induced by the introduction of significantly altered surface charge as a result of the neutralization reaction.

Figure 1 (e-h) shows high-resolution TEM images comparing few-layer GO and $\mathrm{GO}_{\text {Кон }}$ sheets. In the lower magnification images, $\mathrm{GO}$ appears much lighter compared to $\mathrm{GO}_{\mathrm{KOH}}$. This may simply be due to a difference in thickness of the samples. At the edges of both samples, slightly brighter areas indicate even thinner regions, a few monolayers thick. Some crumpling and folding is also observed. At high magnification, the hexagonal arrangement of the underlying carbon in GO can be resolved in some regions. However in $\mathrm{GO}_{\mathrm{KOH}}$, such detail could not be resolved.

\section{$\underline{3.2 X-r a y ~ P h o t o e l e c t r o n ~ S p e c t r o s c o p y ~}$}

XPS was performed on $\mathrm{GO}$ and $\mathrm{GO}_{\mathrm{KOH}}$ for chemical and elemental analysis. Error! Reference source not found.a shows the wide scan spectrum with three major peaks corresponding to $\mathrm{O} 1 \mathrm{~s}(532 \mathrm{eV}), \mathrm{K}$ 2 p $(292 \mathrm{eV})$, and C 1s $(284 \mathrm{eV})$. The elemental composition is: $77.5 \%$ carbon and $22.5 \%$ oxygen for $\mathrm{GO}$; and $78.5 \%$ carbon, $15.9 \%$ oxygen, and $5.7 \%$ potassium for $\mathrm{GO}_{\mathrm{KOH}}$. The oxygen content is slightly lower in $\mathrm{GO}_{\mathrm{KOH}}$. Error! Reference source not found.b shows the $\mathrm{C} 1 \mathrm{~s}$ spectra deconvoluted into six peaks ascribed to different bonds. $\mathrm{GO}_{\mathrm{KOH}}$ shows a clear decrease in the proportion of epoxy groups. The proportion of hydroxyl groups decreases slightly and an energy shift is observed, as a result of the cation exchange reaction. The deconvoluted O 1s spectra are shown in Error! Reference source not found.c. The decreased intensity reflects the decreased oxygen content in $\mathrm{GO}_{\mathrm{KOH}}$. Epoxy groups are highly reactive due to the highly strained bonds, and open up to generate hydroxyls in basic environment [46]. The peak at $\sim 530.6 \mathrm{eV}$ indicates oxygen-alkali bonds, providing evidence of successful cation exchange [47]. Error! Reference source not found.d shows two potassium peaks at $292.8 \mathrm{eV}$ and $295.6 \mathrm{eV}$ attributed to the $\mathrm{K} 2 \mathrm{p}_{3 / 2}$ and $\mathrm{K} 2 \mathrm{p}_{1 / 2}$ spin-orbit-split doublet of potassium oxides and cations. The $\mathrm{K} 2 \mathrm{p}_{3 / 2}$ peak is deconvoluted into two contributions reflecting the different chemical environments of potassium ions. The major assignment is at $292.7 \mathrm{eV}$ for the potassium associated with the carboxylic acid groups of GO, located in a position similar to that of the analogous small molecule potassium acetate [48], whilst a minor contribution is attributed to unbound $\mathrm{KOH}$. The 
presence of $\mathrm{K}-\mathrm{O}$ bonds and the decreased proportion of epoxy and hydroxyl functional groups confirm the successful chemical modification of GO. The decrease in oxygen content, especially of certain functional groups indicates partial reduction of GO in the strongly alkaline environment ( $\mathrm{pH} 12.5$ ), as previously reported $[49,50]$.

\subsection{X-ray Diffraction (XRD)}

Error! Reference source not found.a shows XRD spectra of GO and $\mathrm{GO}_{\mathrm{KOH}}$ measured at ambient temperature and relative humidity. GO has a major peak at $2 \theta=11.53^{\circ}$ corresponding to an interlayer distance of $0.77 \mathrm{~nm}$, similar to reported values under similar conditions [32]. $\mathrm{GO}_{\mathrm{KOH}}$ has a major peak at $2 \theta=10.32^{\circ}$ corresponding to a much larger interlayer spacing of $0.86 \mathrm{~nm}$. In general, the interlayer spacing in GO decreases with decreasing oxygen content [51]. The larger interlayer spacing in $\mathrm{GO}_{\mathrm{KOH}}$ despite the lower oxygen content reflects the much larger ionic radius of $\mathrm{K}^{+}$ions $(\sim 0.13 \mathrm{~nm})$ [52], compared with $\mathrm{H}^{+}\left(\sim 8.4 \times 10^{-7} \mathrm{~nm}\right)$ [53]. The appearance of a second peak in the $\mathrm{GO}_{\mathrm{KOH}}$ spectrum at $2 \theta=21.2^{\circ}$ corresponds to an interlayer spacing of $0.42 \mathrm{~nm}$. This has been associated with potassiumgraphite intercalation compounds [54], and may be a further indicator of partial reduction of the GO to a graphite-like state. The lack of characteristic Bragg reflections for bulk $\mathrm{KOH}$ indicates that little or no excess $\mathrm{KOH}$ is present [55].

\subsection{Gas Barrier Properties}

Crossover of hydrogen from the anode to cathode is an important issue in fuel cells and should be avoided. One of the main advantages of using GO as an ionomer membrane is that it is highly impermeable, and therefore crossover should be minimal. As a result of this, much thinner membranes could be utilized, reducing cell resistance. Here we measure the hydrogen gas barrier properties of membranes with different thickness (GO: 17 and $37 \mu \mathrm{m}$; $\mathrm{GO}_{\mathrm{KOH}}: 15$ and $37 \mu \mathrm{m}$ ) at $30^{\circ} \mathrm{C}$. Error! Reference source not found.b shows the permeance and permeability. The values are extremely low for both membranes; and several orders of magnitude lower than Nafion ( $\sim 25$ barrer). The hydrogen permeance decreases with increasing thickness for both $\mathrm{GO}$ and $\mathrm{GO}_{\mathrm{KOH}}$. This is as expected since the permeance is the pressure-normalized gas flux though the membrane and is dependent on the diffusion coefficient (constant), the concentration of permeate (constant), and the thickness of the membrane. The permeability is approximately constant with thickness, as expected for this thickness-normalized value. These results are contrary to a previous high-profile study which claims that GO is completely impermeable to liquids and gases except water [56]. This disparity is attributed to the much larger pressure differential used in our work, resulting in higher, more measurable hydrogen permeation rates. The permeance and permeability of $\mathrm{GO}_{\mathrm{KOH}}$ are around 5 times lower than in $\mathrm{GO}$, indicating that $\mathrm{KOH}$ treatment can improve the hydrogen gas barrier properties, despite the larger interlayer spacing. This may be due to the added effect of potassium ions, which completely change the electronic structure within the membrane. As such, both $\mathrm{GO}$ and $\mathrm{GO}_{\mathrm{KOH}}$ membranes are ideally suited to minimize crossover in fuel cells.

\subsection{Mechanical Strength and Water Uptake}

The tensile strength $(24.5 \pm 2.0 \mathrm{MPa})$ and Young's modulus $(290.3 \pm 66 \mathrm{MPa})$ of $\mathrm{GO}_{\mathrm{KOH}}$ are smaller compared to our previously reported values for GO $(54.5 \pm 3.3 \mathrm{MPa}$ and $680 \pm 9.7 \mathrm{MPa}$, respectively) [32]. This may be due to reduced van der Waals forces between the individual $\mathrm{GO}_{\mathrm{KOH}}$ sheets because of the intercalated potassium ions. However, the values are comparable to conventional ionomer materials. The elongation before rupture is $11 \pm 1.6 \%$, significantly lower than previously observed for GO $(22 \pm 1 \%)$. 
The water uptake of GO is $1434 \mathrm{wt} \%$, compared with $1099 \mathrm{wt} \%$ for $\mathrm{GO}_{\mathrm{KOH}}$. The lower water uptake in $\mathrm{GO}_{\mathrm{KOH}}$ is attributed to lower oxygen content and therefore reduced hydrophilicity. Both membranes show an extremely high degree of swelling, much greater than we previously reported (i.e. $31 \%$ at $80^{\circ} \mathrm{C}$ ), and resembling a hydrogel [57]. The high degree of swelling is attributed to the smaller area of the membrane samples allowing water absorption throughout the entire membrane on much faster timescales.

\subsection{Thermal Stability}

The thermal stabilities of $\mathrm{GO}$ and $\mathrm{GO}_{\mathrm{KOH}}$ were investigated by thermogravimetric analysis (TGA) in air. GO displays four main mass loss peaks (Error! Reference source not found.). The endothermic peak centered at $\sim 80^{\circ} \mathrm{C}$ is associated with evaporation of physisorbed water intercalated in the GO. There is a small exothermic mass loss peak at around $160^{\circ} \mathrm{C}$ which we attribute to early onset reduction of the GO, i.e. the decomposition of one of the weakly-bonded functional groups (e.g. -OH), or loss of chemically bound water molecules. The exothermic mass loss peak at $\sim 220^{\circ} \mathrm{C}$ is attributed to decomposition of all other oxygen-containing functional groups. The final exothermic mass loss peak at $\sim 520^{\circ} \mathrm{C}$ is attributed to combustion of the remaining carbon to form $\mathrm{CO}_{2}$.

$\mathrm{GO}_{\mathrm{KOH}}$ also exhibits four mass-loss peaks. The first is related to water evaporation, at $\sim 80^{\circ} \mathrm{C}$. A small exothermic mass loss occurs at $140^{\circ} \mathrm{C}$, again attributed to loss of weakly bound oxygen-containing functional groups or chemically bound water. The third, exothermic mass loss peak occurs at $\sim 380^{\circ} \mathrm{C}$ attributed to the formation of potassium carbonate. This is more themally stable than carbon and accounts for the stability of this phase up to $>800^{\circ} \mathrm{C}$. Finally, two strong endothermic signals corresponding to the glass transition and melting points of $\mathrm{K}_{2} \mathrm{CO}_{3}$ are observed [58], followed by complete mass loss at around $1100^{\circ} \mathrm{C}$, corresponding to decomposition of $\mathrm{K}_{2} \mathrm{CO}_{3}$ to $\mathrm{CO}_{2}$ and gaseous potassium. These results show that $\mathrm{GO}_{\mathrm{KOH}}$ is slightly less thermally stable than GO.

\subsection{Ion Exchange Capacity, Ionic Conductivity, and Activation Energy}

The ion exchange capacity (IEC) of the membranes, i.e. the number of moles of charge carrier per unit mass, was determined by titration. The GO and $\mathrm{GO}_{\mathrm{KOH}}$ membranes have IECs of approximately 2.6 and $6.1 \mathrm{mmol} / \mathrm{g}$ for $\mathrm{H}^{+}$and $\mathrm{OH}^{-}$respectively. As there is a slight excess of $\mathrm{OH}$ - in the alkaline membrane compared to the $\mathrm{H}^{+}$present in the untreated membrane, we conclude that there is a small excess of free $\mathrm{KOH}$ in the $\mathrm{GO}_{\mathrm{KOH}}$ membrane, as confirmed by the K $2 p$ XPS data. This excess of $\mathrm{KOH}$ also explains why the IEC is higher than in commercially available membranes, e.g. $1.8 \mathrm{mmol} / \mathrm{g}$ for Tokuyama A201.

Impedance spectroscopy was used to determine the through-plane ionic conductivity of the membranes. Error! Reference source not found.a shows the dependence of conductivity on humidity and temperature for $\mathrm{GO}_{\mathrm{KOH}}$. The proton conductivity of $\mathrm{GO}$ at $100 \% \mathrm{RH}$ is included for comparison. In general, the conductivity increases with increasing humidity and increasing temperature. This is as expected for ionic charge carriers, in which higher temperature overcomes the activation barrier for ion mobility and high humidity provides enhanced ion mobility via water-mediated transport mechanisms. The highest anionic conductivity of $\mathrm{GO}_{\mathrm{KOH}}$ is $6.1 \mathrm{mS} / \mathrm{cm}$ at $70^{\circ} \mathrm{C}$ and $100 \% \mathrm{RH}$. This is around 20 times higher than the value of proton conductivity of GO, suggesting that the alkaline ion exchange reaction was successful in fundamentally changing the nature of ion transport in the material. It compares reasonably well with commercially available AAEMs, e.g. Tokuyama A201, which has a through-plane conductivity of $7.1 \mathrm{mS} / \mathrm{cm}$ at $30^{\circ} \mathrm{C}[59]$. 
However, at low humidity and high temperature $\left(70^{\circ} \mathrm{C}\right)$ the conductivity of the $\mathrm{GO}_{\mathrm{KOH}}$ membranes increases with decreasing humidity, as also observed for GO membranes [33]. This is indicative of electronic conduction under these conditions. At high humidity electronic conductivity is negligible due to the presence of intercalated water and the large interlayer spacing, blocking electron-conducting pathways between $\mathrm{sp}^{2}$ regions of the carbon. At low relative humidity the interlayer spacing decreases as water is removed from the membrane [60]. This provides the opportunity for electron percolation from layer to layer, along a pathway of local $\mathrm{sp}^{2}$ regions [61]. Although electronic conduction is not desirable in fuel cell membranes, this effect is not observed under fuel cell conditions (i.e. high humidity), and additionally there are potential applications of GO membranes as mixed ionic conductors.

Arrhenius plots of the conductivity data are presented for different humidities in Error! Reference source not found.b. The slopes correspond to activation energies, which are plotted against humidity in Error! Reference source not found.c. Due to the unusual behavior observed at $70^{\circ} \mathrm{C}$ and attributed to mixed conduction, fitting was limited to the 30 to $60^{\circ} \mathrm{C}$ range. The activation energies are quite high at high humidity $\left(\sim 0.4 \mathrm{eV}\right.$, or $\left.38.6 \mathrm{~kJ} \mathrm{~mol}^{-1}\right)$. Generally values of between $\sim 0.1-0.2 \mathrm{eV}(\sim 10-25$ $\mathrm{kJ} / \mathrm{mol}$ ) [62,63], are reported for anion conducting membranes. The activation energy gradually decreases with decreasing humidity, possibly related to the gradual change in interlayer spacing with RH. At low RH, the activation energy is just $0.01 \mathrm{eV}(1.0 \mathrm{~kJ} / \mathrm{mol})$, most likely indicating electron transfer, and confirming that the membranes are mixed ionic conductors when dry. The larger activation energy compared with conventional anion membranes accounts for the low conductivity despite the large IEC.

\subsection{Determination of Dominating Ionic Species}

Blocking layer measurements were performed on the membranes in order to confirm the dominance of $\mathrm{OH}^{-}$anion conduction, and to discount $\mathrm{H}^{+}$or $\mathrm{K}^{+}$ion conduction (Error! Reference source not found.d). Accordingly, $\mathrm{GO}_{\mathrm{KOH}}$ membranes were sandwiched between anion-blocking (Nafion) or cation-blocking (Tokuyama) layers, as shown schematically in Error! Reference source not found.e. The negatively charged $\mathrm{SO}^{3-}$ groups in Nafion block $\mathrm{OH}^{-}$ions by electrostatic repulsion, just as the positively charged cations in Tokuyama membranes repel protons. When proton-blocking layers are utilized, the conductivity closely follows that of $\mathrm{GO}_{\mathrm{KOH}}$ with no blocking layers. When anion-blocking layers are used, the conductivity drops significantly across the whole temperature range. These results confirm that the dominant charge carriers are $\mathrm{OH}^{-}$anions. These results also discount majority $\mathrm{K}^{+}$ conduction, since neither blocking layer is a known $\mathrm{K}^{+}$conductor. However, a small proportion of $\mathrm{H}^{+}$ conduction appears to occur $(\sim 6 \%)$. A small discrepancy is observed between the reference sample and the sum of the anion- and proton-blocked samples, especially at higher temperature. This may be due to a small amount of $\mathrm{K}^{+}$conduction, or potassium carbonate formation and associated $\mathrm{CO}_{3}{ }^{2-}$ ion conduction [2]. However due to the barrier properties of GO and nanoconfinement between the individual GO sheets, movement of such ions through the membrane by the vehicular mechanism is expected to be highly restricted [56]. The discrepancy may also be attributed to a small proportion of electronic conduction.

The above results confirm that the dominant charge carriers in $\mathrm{GO}_{\mathrm{KOH}}$ membranes at high humidity are $\mathrm{OH}^{-}$ions. The specific mechanism for $\mathrm{OH}^{-}$conduction in $\mathrm{GO}_{\mathrm{KOH}}$ is hypothesized to be either vehicular, or reverse Grotthuss. In the vehicular mechanism, an $\mathrm{OH}^{-}$ion physically travels through the membrane. However, this is problematic in the case of GO, since it is widely accepted that due to the highly impermeable nature of this material, only protons and water can pass between GO sheets. The reverseGrotthuss mechanism is related to the conventional Grotthuss mechanism, in which acidic protons hop from e.g. a hydronium ion $\left(\mathrm{H}_{3} \mathrm{O}^{+}\right)$to a water molecule, forming a new hydronium ion and leaving 
behind a water molecule. The reverse-Grotthuss mechanism dominates in alkaline conditions, where there is a large excess of $\mathrm{OH}^{-}$ions. Here, protons hop from a water molecule onto an adjacent $\mathrm{OH}^{-}$ion, forming a new water molecule and leaving behind a new $\mathrm{OH}^{-}$ion [64-66]. In this way the diffusion of positively charged protons effectively results in a net backwards diffusion of $\mathrm{OH}^{-}$ions (schematically represented in Error! Reference source not found.). This is analogous to the transport of vacancies in p-type semiconductors, or the transport of $\mathrm{O}^{2-}$ ions in solid oxide fuel cell (SOFC) electrolytes. The activation energy for Grotthuss-type proton hopping is expected to be much lower $(\sim 0.13 \mathrm{eV})$ than the measured $0.4 \mathrm{eV}$ [65]. This hints that nanoconfinement between the layers of GO fundamentally affects the activation energy required for ionic transport, due to steric effects [67].

\subsection{Fuel Cell Performance}

Due to the interesting anion conductivity measured in these novel AAEMs, a proof-of-concept AAEMFC was fabricated. A single-cell MEA was prepared using an $18 \mu \mathrm{m}$ thick $\mathrm{GO}_{\mathrm{KOH}}$ electrolyte membrane, and installed in a fuel cell test system. Error! Reference source not found.a shows the resulting polarization curves and power density of the cell. The open circuit voltage (OCV) is $0.94 \mathrm{~V}$. This is reasonable, but still lower than for commercially available AAEMs (1.02 V), or for protonconducting GOMFCs (1.01 V) [32]. The low OCV cannot be attributed to fuel crossover, because of the excellent hydrogen barrier properties of the membrane. Therefore, it is attributed to mixed ionic conductivity, as observed in the blocking layer measurements. There is a small initial voltage drop of $\sim 0.05 \mathrm{~V}$ attributed to activation losses. This is much smaller than observed in GOMFCs $(\sim 0.2 \mathrm{~V})$, reflecting the faster reaction kinetics in alkaline environment. The ohmic region is linear but steep, indicating relatively high ohmic losses. From this slope, the total cell resistance is calculated to be 204 $\Omega \mathrm{cm}^{2}$, around 1000 times higher than in AAEMFCs made with commercially available anion conducting membranes [69]. The resistance of the membrane is calculated to be $0.48 \Omega \mathrm{cm}^{2}$ from the conductivity measurements at $30^{\circ} \mathrm{C}$, so this is clearly not the main contributor to the cell resistance. Therefore it is attributed to the electrocatalyst layer, or the interface between the electrocatalyst layer and the membrane. Hot pressing is usually utilized during fabrication of MEAs in order to improve contact between ionomer and the electrocatalyst. In $\mathrm{GO}_{\mathrm{KOH}}$ AAEMFCs the hot-pressing step was omitted, since high temperature reduces GO and destroys the ion-conducting properties. Therefore the interaction between the polymer anion-conducting ionomer and the electrocatalyst is not optimized, increasing the resistance of the layer. Additionally, the presence of $\mathrm{KOH}$ in the membrane could lead to the formation of potassium carbonate upon exposure to $\mathrm{CO}_{2}$ in the air. Many studies utilize pure oxygen rather than air at the cathode to prevent this, but such conditions are not realistic for practical fuel cells. Carbonate formation leads to neutralization of the membrane, quickly decreasing the conductivity (i.e. increasing the resistance) [2]. The carbonate could also potentially result in an inert layer at the interface with the electrocatalyst, acting as a barrier to ion conduction and increasing the cell resistance. No mass transport limited region is observed, due to the relatively low power density. The maximum power density is $0.97 \mathrm{~mW} / \mathrm{cm}^{2}$ at $2.09 \mathrm{~mA} / \mathrm{cm}^{2}$. This is much lower than in commercial AAEMFCs operated under similar condition (e.g. 8 to $100 \mathrm{~mW} / \mathrm{cm}^{2}$ ) [12]. Improvements in the performance of $\mathrm{GO}_{\mathrm{KOH}}$ AAEMFCs are expected by optimization of the ionomer-catalyst ratio in the electrocatalyst layer; utilizing pure oxygen rather than air; decreasing the membrane thickness; and laminating the $\mathrm{GO}_{\mathrm{KOH}}$ with thin polymeric anion conducting layers [70]. However, despite the relatively low power density at present, this is an important proof-of-concept device.

The durability of the $\mathrm{GO}_{\mathrm{Kон}}$ AAEMFC was investigated at $30^{\circ} \mathrm{C}$ at a constant load current of $1 \mathrm{~mA}$ (Error! Reference source not found.b). The cell voltage drops significantly in the first 5 minutes of operation. After the initial drop in cell voltage, a slower degradation in performance is observed. Similar behavior was reported in acid-based GOMFCs, and related to reduction of GO in the strongly reducing hydrogen atmosphere increasing the proportion of electronic conduction through the membrane [32]. In less than an hour the cell voltage dropped by $0.5 \mathrm{~V}$, to $0.2 \mathrm{~V}$. After the durability measurement, the cell performance was again investigated. The OCV was just $0.65 \mathrm{~V}$, confirming that 
increased electronic conductivity is a factor in the degradation process. The maximum power density was just $0.44 \mathrm{~mW} / \mathrm{cm}^{2}$ at $1.60 \mathrm{~mA} / \mathrm{cm}^{2}$.

\section{4.\# Conclusions}

Novel alkali anion exchange membranes were prepared via cation exchange of pure graphene oxide dispersions, followed by simple vacuum filtration. Hydrogen gas permeation through the membranes was several orders of magnitude below that of conventional polymers. The maximum conductivity was $6.1 \mathrm{mS} / \mathrm{cm}$ at $70^{\circ} \mathrm{C}$, approaching that of commercially available anion conducting membranes, and the dominant charge carrier was confirmed to be $\mathrm{OH}^{-}$, by careful use of blocking layer measurements. A demonstration alkaline fuel cell utilizing a $\mathrm{GO}_{\mathrm{KOH}}$ membrane was fabricated. The initial OCV was $0.94 \mathrm{~V}$, and the maximum power density was $\sim 1 \mathrm{~mW} / \mathrm{cm}^{2}$. The relatively low performance is attributed to carbonate formation upon exposure to $\mathrm{CO}_{2}$, and the fact that hot pressing cannot be used without reducing the graphene oxide, and we are now working on these engineering challenges. However, this is an original and important proof-of-concept for the application of pure graphene oxide-based alkaline exchange membranes in electrochemical devices.

\section{Acknowledgements}

The authors gratefully acknowledge the support of the International Institute for Carbon Neutral Energy Research (WPI-I2CNER), sponsored by the World Premier International Research Center Initiative (WPI), MEXT, Japan. This work was also supported by the Japan Science and Technology Agency (JST) through it's "Center of Innovation Science and Technology based Radical Innovation and Entrepreneurship Program (COI Program)". We acknowledge funding from the International Research Center for Hydrogen Energy, Kyushu University. Additionally we thank Prof. Aleksander Staykov for useful discussion.

\section{References}

[1] H. Strathmann, A. Grabowski, G. Eigenberger, Ion-Exchange Membranes in the Chemical Process Industry, Ind. Eng. Chem. Res. 52 (2013) 10364-10379.

[2] J.R. Varcoe, P. Atanassov, D.R. Dekel, A.M. Herring, M. a. Hickner, P. a. Kohl, et al., Anionexchange membranes in electrochemical energy systems, Energy Environ. Sci. 7 (2014) 31353191 .

[3] R.S.L. Yee, R. a. Rozendal, K. Zhang, B.P. Ladewig, Cost effective cation exchange membranes: A review, Chem. Eng. Res. Des. 90 (2012) 950-959.

[4] Y. Wang, K.S. Chen, J. Mishler, S.C. Cho, X.C. Adroher, A review of polymer electrolyte membrane fuel cells: Technology, applications, and needs on fundamental research, Appl. Energy. 88 (2011) 981-1007.

[5] S.J. Peighambardoust, S. Rowshanzamir, M. Amjadi, Review of the proton exchange membranes for fuel cell applications, Elsevier Ltd, 2010.

[6] J. Zaidi, T. Matsuura, eds., Polymer Membranes for Fuel Cells, 1st ed., Springer US, 2009. 
[7] S.Q. Song, W.J. Zhou, W.Z. Li, G. Sun, Direct Methanol Fuel Cells : Methanol Crossover and its Influence on Single D M F C Performance, Ionics (Kiel). 10 (2004) 458-462.

[8] K.D. Baik, B.K. Hong, M.S. Kim, Effects of operating parameters on hydrogen crossover rate through Nafion ${ }^{\circledR}$ membranes in polymer electrolyte membrane fuel cells, Renew. Energy. 57 (2013) 234-239.

[9] L. Jianfeng, K. Sasaki, S.M. Lyth, Pt-decorated Graphene-like Foam for Electrochemical Oxygen Reduction with High Mass Activity, ECS Trans. 58 (2013) 1751-1762.

[10] J. Liu, D. Takeshi, D. Orejon, K. Sasaki, S.M. Lyth, Defective Nitrogen-Doped Graphene Foam: A Metal-Free, Non-Precious Electrocatalyst for the Oxygen Reduction Reaction in Acid, J. Electrochem. Soc. 161 (2014) F544-F550.

[11] J.J. Baschuk, X. Li, Carbon monoxide poisoning of proton exchange membrane fuel cells, Int. J. Energy Res. 25 (2001) 695-713.

[12] G. Merle, M. Wessling, K. Nijmeijer, Anion exchange membranes for alkaline fuel cells: A review, J. Memb. Sci. 377 (2011) 1-35.

[13] T. Xu, Ion exchange membranes: State of their development and perspective, J. Memb. Sci. $263(2005) 1-29$.

[14] R.C.T. Slade, J.P. Kizewski, S.D. Poynton, R. Zeng, J.R. Varcoe, Alkaline Membrane Fuel Cells, in: R.A. Meyers (Ed.), Fuel Cells Sel. Entries from Encycl. Sustain. Sci. Technol., 2013: pp. 9-29.

[15] A.M. Bartrom, J.L. Haan, The direct formate fuel cell with an alkaline anion exchange membrane, J. Power Sources. 214 (2012) 68-74.

[16] T.S. Zhao, Y.S. Li, S.Y. Shen, Anion-exchange membrane direct ethanol fuel cells: Status and perspective, Front. Energy Power Eng. China. 4 (2010) 443-458.

[17] M. U nlu , J. Zhou, P. a. Kohl, Hybrid Anion and Proton Exchange Membrane Fuel Cells, J. Phys. Chem. C. 113 (2009) 11416-11423.

[18] C.G. Arges, V. Ramani, P.N. Pintauro, Anion Exchange Membrane Fuel Cells, Interface. 19 (2010) 31-35.

[19] J. Liu, K. Sasaki, S.M. Lyth, Defective Nitrogen-Doped Graphene Foam: A Non-Precious Electrocatalyst for the Oxygen Reduction Reaction in Alkaline Medium, ECS Trans. 64 (2014) $1161-1172$.

[20] Y.-J. Wang, J. Qiao, R. Baker, J. Zhang, Alkaline polymer electrolyte membranes for fuel cell 
applications, Chem. Soc. Rev. 42 (2013) 5768-5787.

[21] C. Yang, Study of alkaline nanocomposite polymer electrolytes based on PVA - ZrO $2-\mathrm{KOH}$, Mater. Sci. Eng. 131 (2006) 256-262.

[22] D.R. Dreyer, S. Park, C.W. Bielawski, R.S. Ruoff, The chemistry of graphene oxide., Chem. Soc. Rev. 39 (2010) 228-240.

[23] W. s. Hummers, R.E. Offeman, Preparation of Graphitic Oxide, Am. Chem. Soc. 80 (1957) 1339.

[24] D.A. Dikin, S. Stankovich, E.J. Zimney, R.D. Piner, G.H.B. Dommett, G. Evmenenko, et al., Preparation and characterization of graphene oxide paper, Nature. 448 (2007) 457-60.

[25] R. Cruz-Silva, A. Morelos-Gomez, H.-I. Kim, H.-K. Jang, F. Tristan, S. Vega-Diaz, et al., Super-stretchable Graphene Oxide Macroscopic Fibers with Outstanding Knotability Fabricated by Dry Film Scrolling., ACS Nano. 8 (2014) 5959-5967.

[26] P. Xiao, J. Gu, J. Chen, J. Zhang, R. Xing, Y. Han, et al., Micro-contact printing of graphene oxide nanosheets for fabricating patterned polymer brushes., Chem. Commun. (Camb). 50 (2014) 7103-7106.

[27] C.-Y. Tseng, Y.-S. Ye, M.-Y. Cheng, K.-Y. Kao, W.-C. Shen, J. Rick, et al., Sulfonated Polyimide Proton Exchange Membranes with Graphene Oxide show Improved Proton Conductivity, Methanol Crossover Impedance, and Mechanical Properties, Adv. Energy Mater. 1 (2011) 1220-1224.

[28] H. Zarrin, D. Higgins, Y. Jun, Z. Chen, M. Fowler, Functionalized Graphene Oxide Nanocomposite Membrane for Low Humidity and High Temperature Proton Exchange Membrane Fuel Cells, J. Phys. Chem. C. 115 (2011) 20774-20781.

[29] C.W. Lin, Y.S. Lu, Highly ordered graphene oxide paper laminated with a Nafion membrane for direct methanol fuel cells, J. Power Sources. 237 (2013) 187-194.

[30] T. Szabó, O. Berkesi, P. Forgó, K. Josepovits, Y. Sanakis, D. Petridis, et al., Evolution of surface functional groups in a series of progressively oxidized graphite oxides, Chem. Mater. 18 (2006) 2740-2749.

[31] H. Tateishi, K. Hatakeyama, C. Ogata, K. Gezuhara, J. Kuroda, a. Funatsu, et al., Graphene Oxide Fuel Cell, J. Electrochem. Soc. 160 (2013) F1175-F1178.

[32] T. Bayer, S.R. Bishop, M. Nishihara, K. Sasaki, S.M. Lyth, Characterization of a Graphene Oxide Membrane Fuel Cell, J. Power Sources. 272 (2014) 239-247.

[33] T. Bayer, S.R. Bishop, N. Perry, K. Sasaki, S.M. Lyth, Tunable Mixed Ionic/Electronic Conductivity and Permittivity of Two Dimensional Graphene, Submitted. (n.d.). 
[34] K. Scott, Ravikumar, Freestanding sulfonated graphene oxide paper: a new polymer electrolyte for polymer electrolyte fuel cells, Chem. Commun. 48 (2012) 5584-5586.

[35] M.R. Karim, K. Hatakeyama, T. Matsui, H. Takehira, T. Taniguchi, M. Koinuma, et al., Graphene Oxide Nanosheet with High Proton Conductivity., J. Am. Chem. Soc. (2013) 0-3.

[36] K. Hatakeyama, M.R. Karim, C. Ogata, H. Tateishi, A. Funatsu, T. Taniguchi, et al., Proton Conductivities of Graphene Oxide Nanosheets: Single, Multilayer, and Modified Nanosheets., Angew. Chem. Int. Ed. Engl. (2014) 6997-7000.

[37] J. Yang, S. Wang, Preparation of graphene-based poly(vinylalcohol)/chitosan nanocomposites membrane for alkaline solid electrolytes membrane, J. Memb. Sci. 477 (2015) 49-57.

[38] O. Movil, L. Frank, J. a. Staser, Graphene Oxide-Polymer Nanocomposite Anion-Exchange Membranes, J. Electrochem. Soc. 162 (2015) F419-F426.

[39] L. Liu, C. Tong, Y. He, Y. Zhao, C. Lü, Enhanced properties of quaternized graphenes reinforced polysulfone based composite anion exchange membranes for alkaline fuel cell, J. Memb. Sci. 487 (2015) 99-108.

[40] H. Zarrin, J. Fu, G. Jiang, S. Yoo, J. Lenos, M. Fowler, et al., Quaternized Graphene Oxide Nanocomposites as Fast Hydroxide Conductors, ACS Nano. 9 (2015) 2028-2037.

[41] H. Chen, J. Wang, H. Bai, J. Sun, Y. Li, Y. Liu, et al., Nanohybrid membranes with hydroxide ion transport highways constructed from imidazolium-functionalized graphene oxide, RSC Adv. 5 (2015) 88736-88747.

[42] S.M. Lyth, R. a. Hatton, S.R.P. Silva, Efficient field emission from Li-salt functionalized multiwall carbon nanotubes on flexible substrates, Appl. Phys. Lett. 90 (2007) 2005-2008.

[43] Recommended Units for Key Parameters, J. Memb. Sci. 443 (2013) II.

[44] K.R. Cooper, Progress Toward Accurate Through-Plane Membrane Resistance and Conductivity Measurement, ECS Trans. 25 (2009) 1-19.

[45] A.M. Abdelkader, C. Valle, A.J. Cooper, I.A. Kinloch, R.A.W. Dryfe, Alkali Reduction of Graphene Oxide in Molten Halide Salts : Production of Corrugated Graphene Derivatives for Supercapacitors, ACS Nano. 8 (2014) 11225-11233.

[46] H.R. Thomas, S.P. Day, W.E. Woodruff, C. Vallés, R.J. Young, I. a. Kinloch, et al., Deoxygenation of graphene oxide: Reduction or cleaning?, Chem. Mater. 25 (2013) 3580-3588.

[47] J. Dupin, D. Gonbeau, A. Levasseur, P. Cedex, T. Cedex, Systematic XPS studies of metal oxides, hydroxides and peroxides, Phys. Chem. Chem. Phys. 2 (2000) 1319-1324. 
[48] R. Jerome, P. Teyssie, J.J. Pireaux, J.J. Verbist, Surface Analysis of Polymers End-Capped with Metal Carboxylates using X-ray Photoelectron Spectroscopy, Appl. Surf. Sci. 27 (1986) 93-105.

[49] S. Park, J. An, R.D. Piner, I. Jung, A. Velamakanni, S.T. Nguyen, et al., Aqueous Suspension and Characterization of Chemically Modified Graphene Sheets Chemically Modified Graphene Sheets, Communications. (2008) 6592-6594.

[50] X. Fan, W. Peng, Y. Li, X. Li, S. Wang, G. Zhang, et al., Deoxygenation of Exfoliated Graphite Oxide under Alkaline Conditions: A Green Route to Graphene Preparation, Adv. Mater. 20 (2008) 4490-4493.

[51] K. Krishnamoorthy, M. Veerapandian, K. Yun, S. Kim, The chemical and structural analysis of graphene oxide with different degrees of oxidation, Carbon N. Y. 53 (2012) 38-49.

[52] E.R. Nightingale, Phenomenological Theory of Ion Solvation . Effective Radii of Hydrated Ions, J. Phys. Chem. 63 (1959) 1381-1387.

[53] R. Pohl, A. Antognini, F.D. Amaro, D.S. Covita, A. Dax, S. Dhawan, et al., The size of the proton, Nat. Lett. 466 (2010) 213-217.

[54] R. Nishitani, Y. Uno, H. Suematsu, In situ observation of staging in potassium-graphite intercalation compounds, Phys. Rev. B. 27 (1983) 6572-6575.

[55] R.G. Snyder, R.G. Snyder, J. Kumamoto, J. Kumamoto, J. a. Ibers, J. a. Ibers, Structure of Potassium Hydroxide: An X-Ray and Infrared Study, J. Chem. Phys. 33 (1960) 1164-1170.

[56] R.R. Nair, H.A. Wu, P.N. Jayaram, I. V. Grigorieva, A.K. Geim, Unimpeded Permeation of Water Through Helium-Leak-Tight Graphene-Based Membranes, Science (80-. ). 335 (2012) 442-444.

[57] A. V Talyzin, T. Hausmaninger, S. You, T. Szabó, The structure of graphene oxide membranes in liquid water, ethanol and water-ethanol mixtures, Nanoscale. 6 (2014) 272-281.

[58] R.L. Lehman, J.S. Gentry, N.G. Glumac, Thermal stability of potassium carbonate near its melting point, Thermochim. Acta. 316 (1998) 1-9.

[59] M. Faraj, E. Elia, M. Boccia, A. Filipi, A. Pucci, F. Cirdelli, New Anion Conducting Membranes Based on Functionalized Styrene- Butadiene-Styrene Triblock Copolymer for Fuel Cells Applications, J. Polym. Sci. Part a-Polymer Chem. 49 (2011) 3437-3447.

[60] T. Daio, T. Bayer, T. Ikuta, T. Nishiyama, K. Takahashi, Y. Takata, et al., In-Situ ESEM and EELS Observation of Water Uptake and Ice Formation in Multilayer Graphene Oxide, Sci. Rep. 5 (2015) 11807. 
[61] D.-W. Wang, A. Du, E. Taran, G.Q. (Max) Lu, I.R. Gentle, A water-dielectric capacitor using hydrated graphene oxide film, J. Mater. Chem. 22 (2012) 21085-21091.

[62] X. Ren, S.C. Price, A.C. Jackson, N. Pomerantz, F.L. Beyer, Highly Conductive Anion Exchange Membrane for High Power Density Fuel-Cell Performance., ACS Appl. Mater. Interfaces. 6 (2014) 13330-13333.

[63] M. Tanaka, K. Fukasawa, E. Nishino, S. Yamaguchi, K. Yamada, H. Tanaka, et al., Anion conductive block poly(arylene ether)s: synthesis, properties, and application in alkaline fuel cells., J. Am. Chem. Soc. 133 (2011) 10646-10654.

[64] J. Fang, J. Qiao, D.P. Wilkinson, J. Zhang, eds., Electrochemical Polymer Electrolyte Membranes, CRC Press, 2015.

[65] M.E. Tuckerman, D. Marx, M. Parrinello, The nature and transport mechanism of hydrated hydroxide ions in aqueous solution, Nature. 417 (2002) 925-929.

[66] M.Ø. Jensen, U. Röthlisberger, C. Rovira, Hydroxide and Proton Migration in Aquaporins, Biophys. J. 89 (2005) 1744-1759.

[67] P. Colomban, ed., Proton conductors: Solids, membranes, and gels-materials and devices, Cambridge University Press, Cambridge, 1993.

[68] K. Momma, F. Izumi, VESTA 3 for three-dimensional visualization of crystal, volumetric and morphology data, J. Appl. Crystallogr. 44 (2011) 1272-1276.

[69] K. Fukuta, H. Inoue, Y. Chikashige, H. Yanagi, Improved Maximum Power Density of Alkaline Membrane Fuel Cells (AMFCs) by the Optimization of MEA Construction, ECS Trans. 28 (2010) 221-225.

[70] A. Paneri, Y. Heo, G. Ehlert, A. Cottrill, H. Sodano, P. Pintauro, et al., Proton selective ionic graphene-based membrane for high concentration direct methanol fuel cells, J. Memb. Sci. 467 (2014) 217-225. 
Figure 1

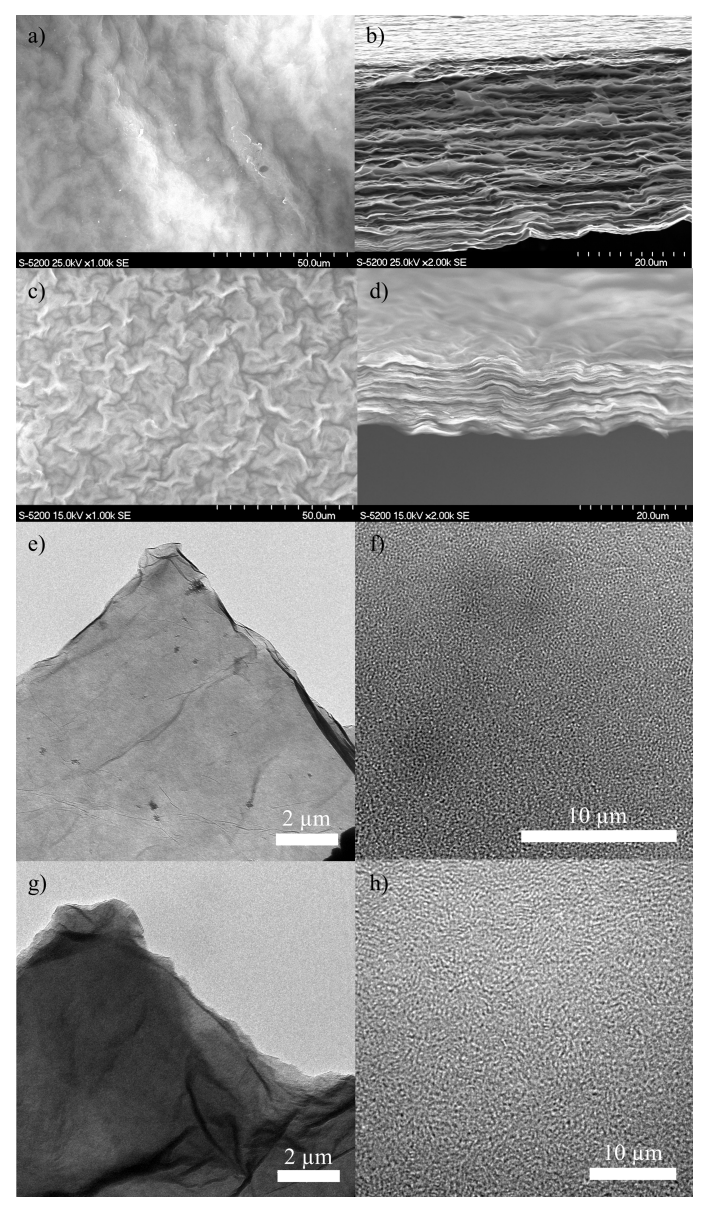


Figure 2
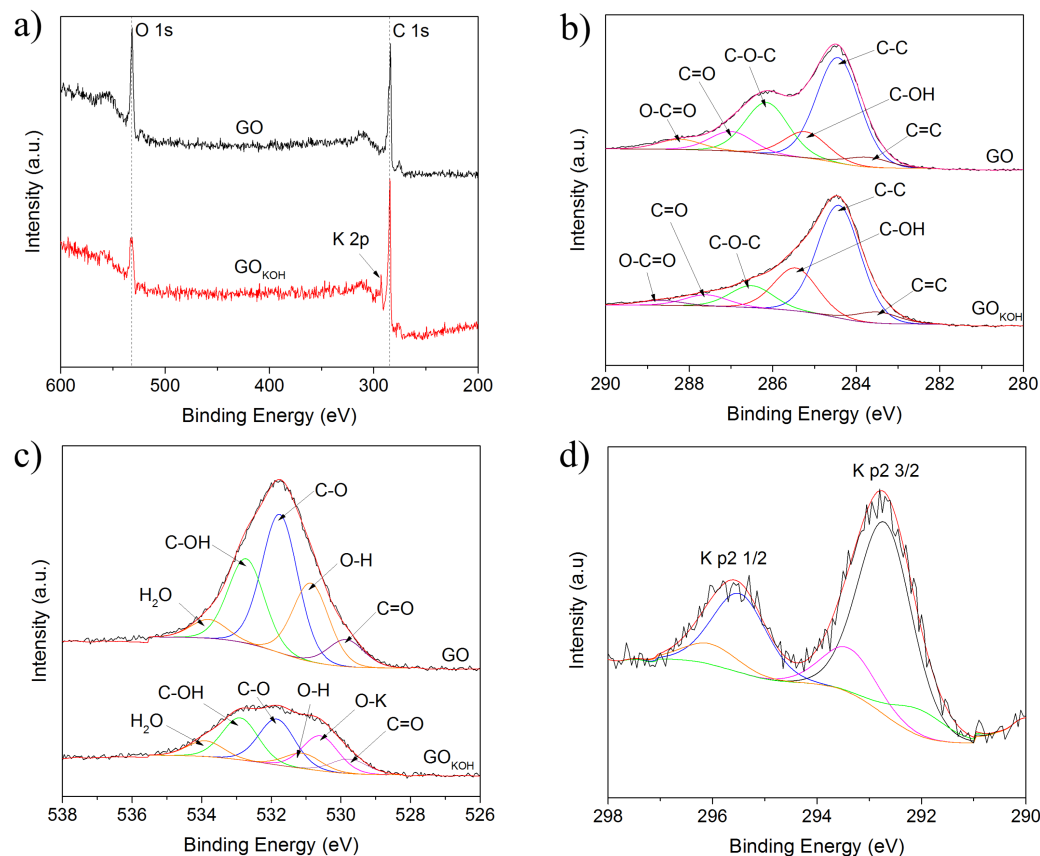
Figure 3
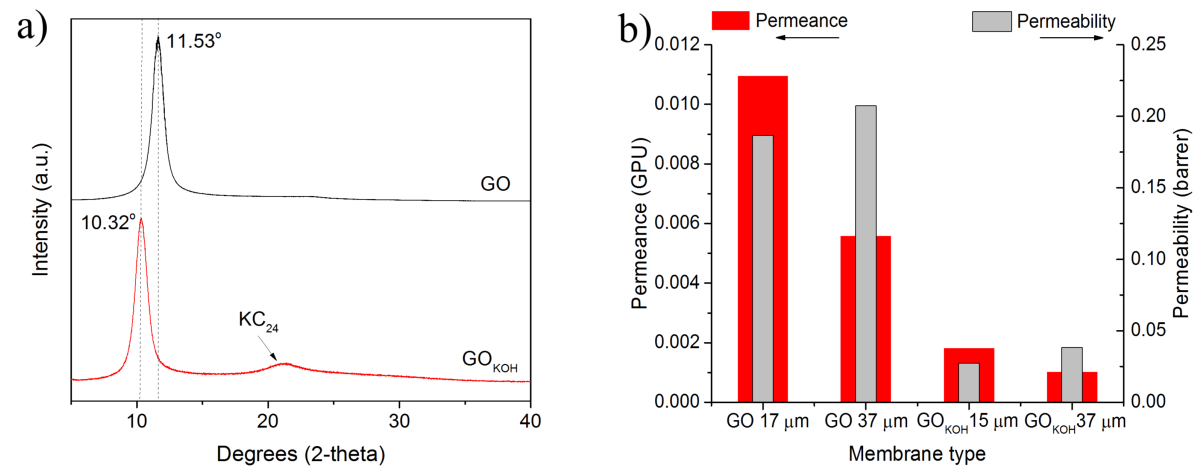
Figure 4

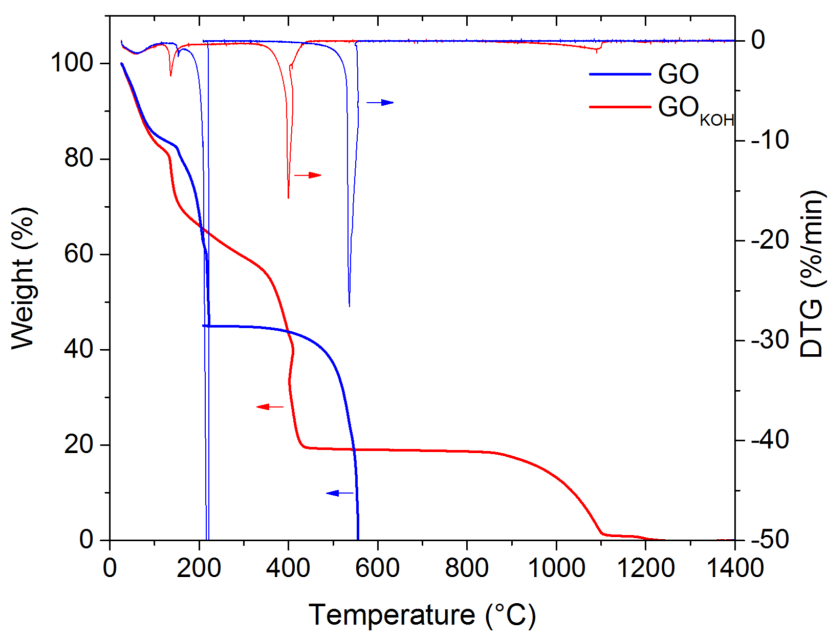


Figure 5
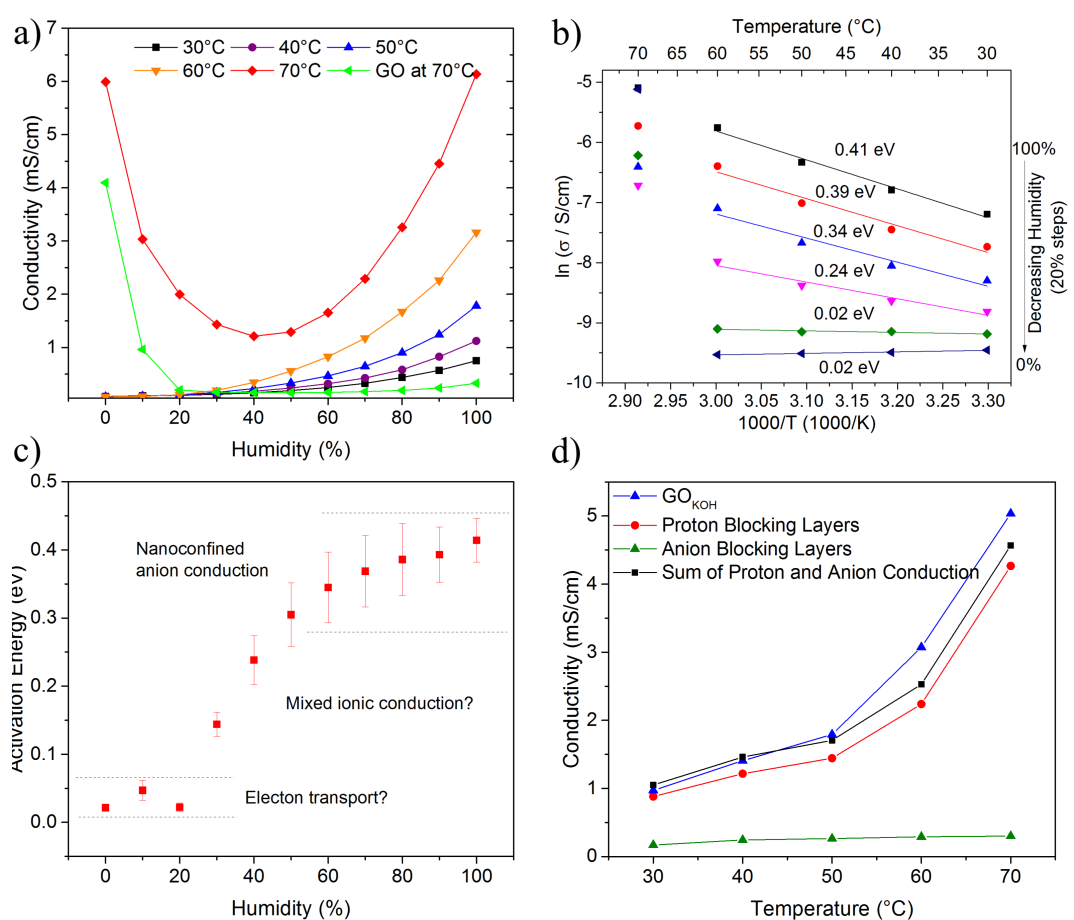

d)

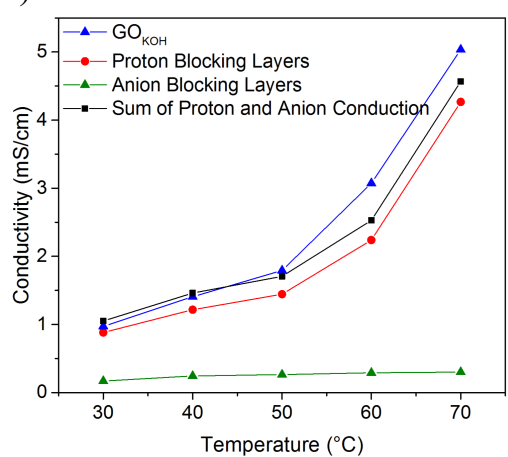

e)

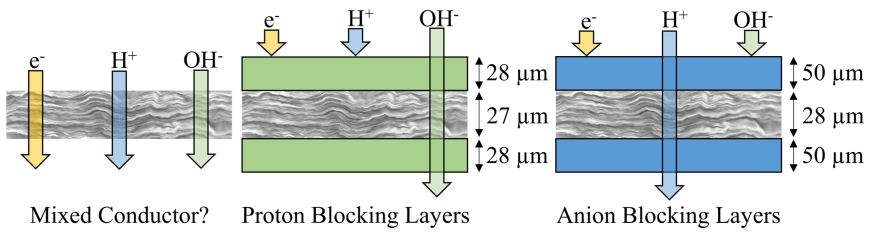


Figure 6

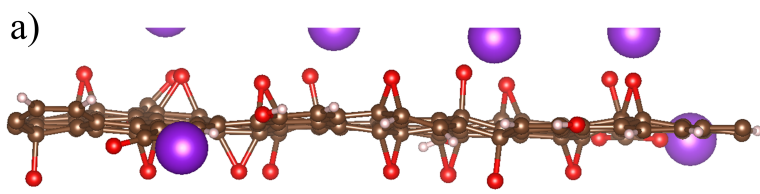

b)
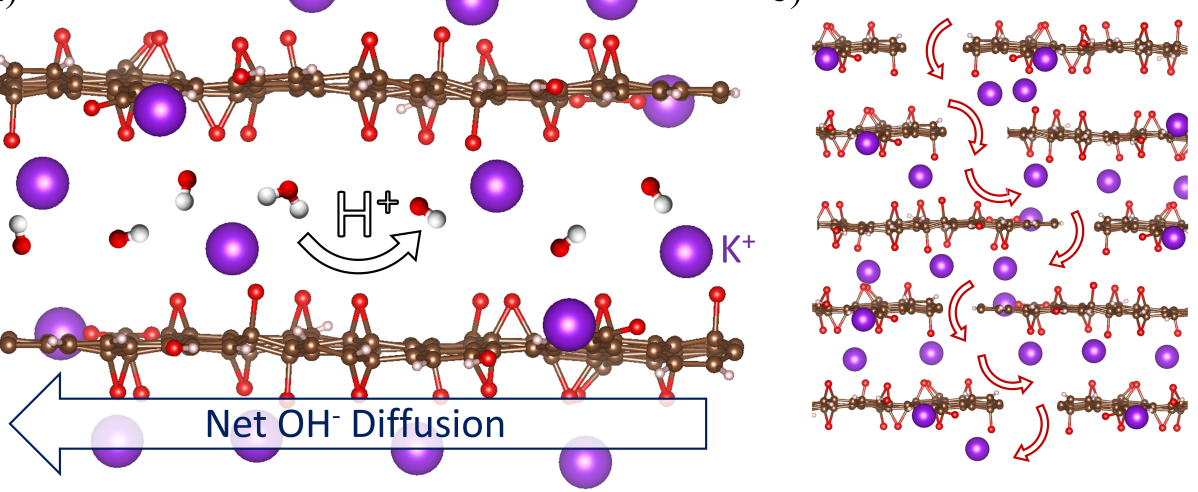
Figure 7
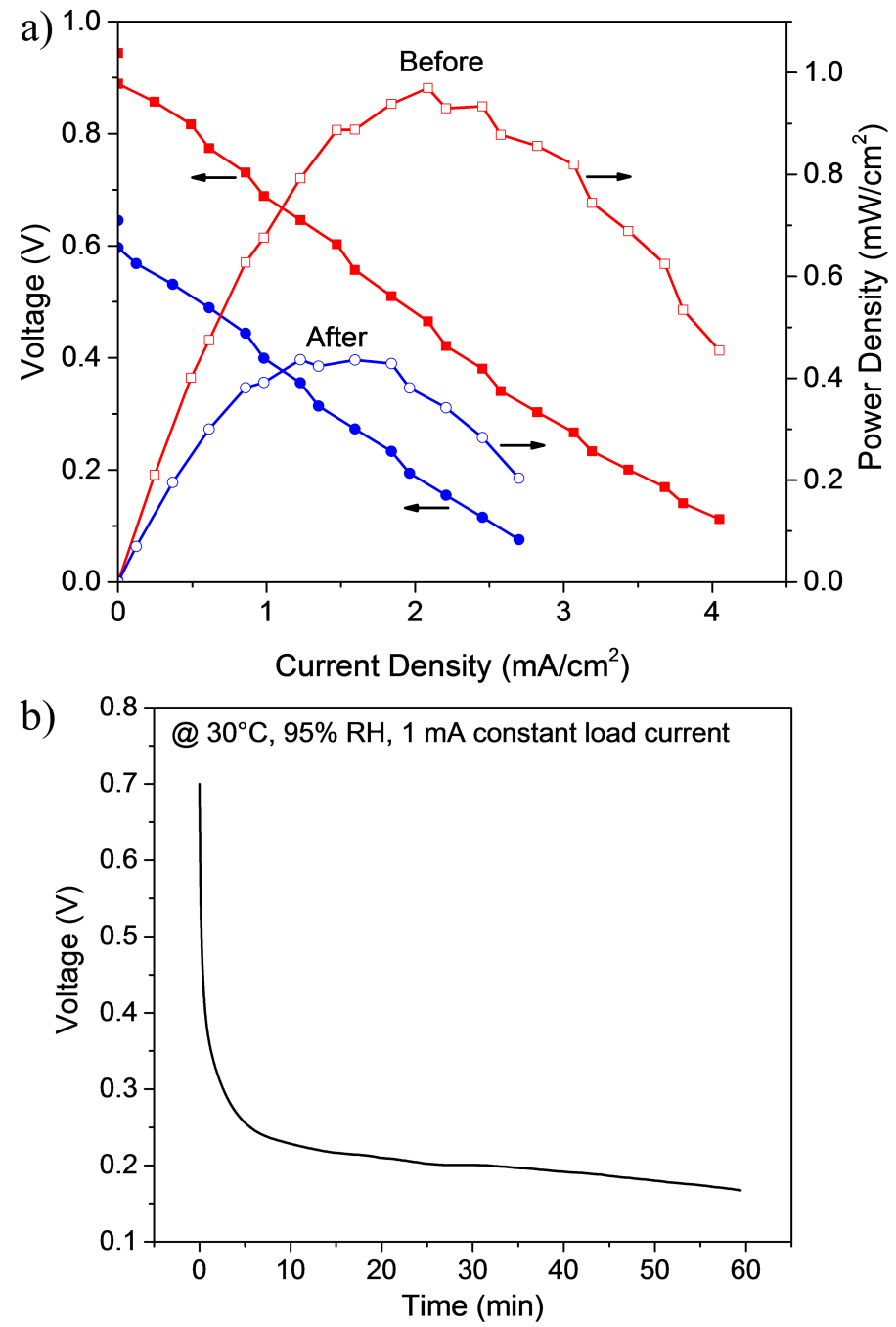
Graphical abstract

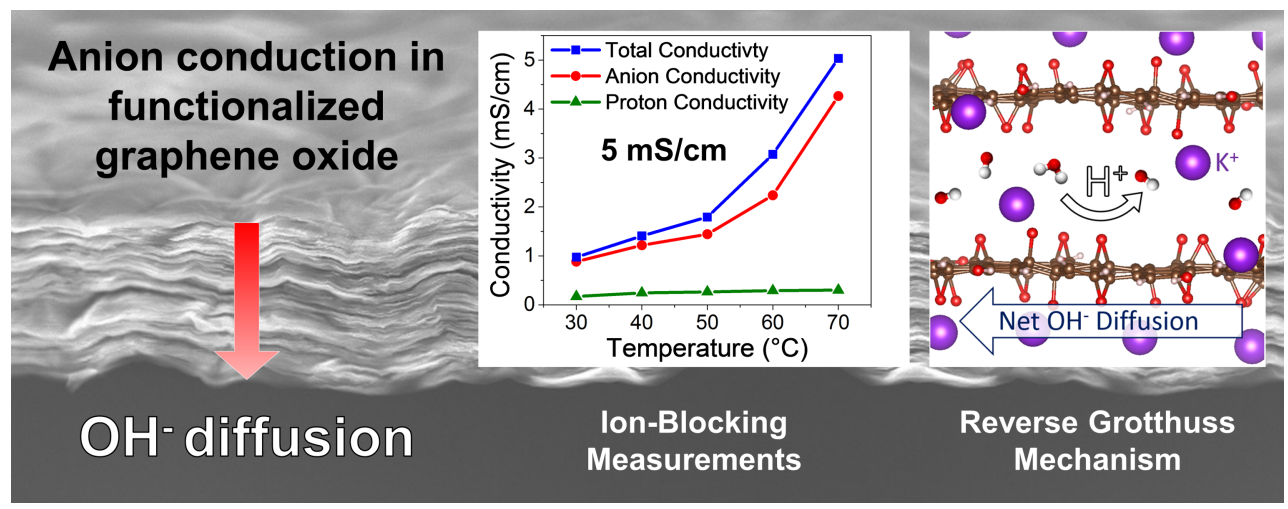

